\section{A J $\mathrm{H}$}

Received : 25.01.2016

Revised : 16.04 .2016

Accepted : 27.04.2016

Members of the Research Forum

Associated Authors:

${ }^{1}$ Department of Vegetable Science,

Horticulture College and Research Institute, ANANTHARAJUPET (A.P.) INDIA

Author for correspondence D. THIRUPAL

Department of Vegetable Science,

Horticulture College and Research

Institute, ANANTHARAJUPET (A.P.)

INDIA

Email : dara.mani7@gmail.com
THE ASIAN JOURNAL OF HORTICULTURE

Volume 11 | Issue 1 | June, 2016 | 72-74

Visit us -www.researchjournal.co.in
RESEARCH PAPER

DOI : 10.15740/HAS/TAJH/11.1/72-74

\title{
Standardization of optimum time planting on broccoli production
}

D. THIRUPAL, G. NARAYANA SWAMY ${ }^{1}$, M. RAVI VENKANNA BABU ${ }^{1}$ AND A. KIREETI ${ }^{1}$

ABSTRACT : The effect of sowing date on the growth and yield of broccoli was studied at Horticulture College and Research Institute, Anantharajupet, YSR Kadapa (Dist), Andhra Pradesh, India, during Rabi season of 2013. Four sowing dates were used in this study viz., $20^{\text {th }}$ November$2013,10^{\text {th }}$ December-2013, 31 ${ }^{\text {st }}$ December-2013 and $20^{\text {th }}$ January-2014 under open field conditions. Significant variations were observed in different growth, yield and quality parameters among the planting dates.The results indicated that significantly higher growth parameters viz., plant height, number of leaves per plant, stalk stem diameter, leaf length, width, petiole length and higher yield components like curd weight, curd length, curd width, yield per hectare, B:C ratio and higher curd quality components viz., ascorbic acid content and shelf-life at room temperature and at $4^{\circ} \mathrm{C}$ were recorded in December $10^{\text {th }}$ planting $\left(\mathrm{D}_{2}\right)$. Minimum days to curd initiation were observed in December $10^{\text {th }}$ planting, whereas least number of days to harvest was observed in January $20^{\text {th }}$ planting $\left(\mathrm{D}_{4}\right)$.

KEY WORDS : Broccoli, Planting dates, Sulphoraphane, Curd weight, Curd yield, B: C ratio, Ascorbic acid, Helf life

HOW TO CITE THIS ARTICLE : Thirupal, D., Narayana Swamy, G., Venkanna Babu, M. Ravi and Kireeti, A. (2016). Standardization of optimum time planting on broccoli production. Asian J. Hort., 11(1) : 72-74, DOI : 10.15740/HAS/TAJH/11.1/72-74. 